\title{
Characterisation of the murine C-type lectin receptor CLECSF8 (MCL) reveals its expression on cells of the Monocyte/Neutrophil lineages and an inter-dependence with Mincle, but not Dectin-2
}

\author{
Bernhard Kerscher ${ }^{1 *}$, Gillian J Wilson ${ }^{1}$, Delyth M Reid ${ }^{1}$, Sho Yamasaki ${ }^{2}$, Janet A Willment ${ }^{1}$, Gordon D Brown ${ }^{1}$ \\ From 1st Annual Meeting of the Scottish Society of Cytomics (SCC) 2014. "Translational Cytometry from \\ Bench to Bedside"
}

Aberdeen, UK. 25 September 2014

\section{Background}

C-type lectin-like receptors (CTLRs) play critical roles in immunity and homeostasis by recognising a great variety of microbial or endogenous ligands [1]. CLECSF8 is a member of the Dectin-2 family of CTLRs. Previous research indicates that CLECSF8 associates with the $\mathrm{FcR} \gamma$ adaptor, which is essential for surface expression and signalling through the SYK/CARD9 pathway. Recently, the mycobacterial cord factor (TDM, trehalose-6,6'-dimycolate) was identified as the ligand of CLECSF8, as shown previously for the closely related CTLR Mincle [2]. Indeed, we recently showed that CLECSF8 plays a critical role in human and murine anti-mycobacterial immunity [3]. In this study, we characterised CLECSF8 expression in the mouse under naïve and inflammatory conditions.

\section{Materials and methods}

We used newly generated anti-CLECSF8 monoclonal antibodies $(\mathrm{mAB})$ to assess receptor expression in the mouse by flow cytometry. The co-dependence of CLECSF8 and Mincle or Dectin-2 was investigated in a transfected fibroblast cell line and primary CLECSF8 ${ }^{-/-}$cells.

\section{Results}

We selected $\mathrm{mAB}$ clone $3 \mathrm{~A} 4$, which was able to recognise CLECSF8 by ELISA and western blot to analyse CLECSF8 expression in the mouse by flow cytometry. While

\footnotetext{
* Correspondence: bernhard.kerscher@abdn.ac.uk

'University of Aberdeen, Institute of Medical Sciences, Aberdeen Fungal Group, Aberdeen, UK

Full list of author information is available at the end of the article
}

CLECSF8 transcript was widely expressed, CLECSF8 protein expression was predominantly found on monocytes/ macrophages and neutrophils within e. g. the peritoneal cavity, blood and bone marrow. Notably, CLECSF8 was expressed only weakly in the lung, but strongly upregulated in a pulmonary Mycobacterium bovis BCG infection model. In vitro, CLECSF8 expression on thioglycollate elicited macrophages was strongly induced upon treatment with TLR agonists or microbial stimuli.

In agreement with previous reports, our data suggests that CLECSF8 associates with the signalling adaptor FcR $\gamma$. Interestingly, surface expression of CLECSF8 in a murine fibroblast cell line was greatly enhanced by cotransfection of Mincle, but not Dectin-2. Intriguingly, Mincle expression mirrored CLECSF8 expression in our in vitro stimulation experiments. Further analyses on wild-type and CLECSF8 ${ }^{-1-}$ primary macrophages in vitro, or cells harvested after intra-peritoneal and intra-tracheal instillation of BCG demonstrated a lack of Mincleupregulation in the absence of CLECSF8.

\section{Conclusion}

CLECSF8 is a predominantly monocyte/macrophage and neutrophil expressed receptor, showing significant interdependence with Mincle, but not Dectin-2.

\footnotetext{
Authors' details

'University of Aberdeen, Institute of Medical Sciences, Aberdeen Fungal Group, Aberdeen, UK. 'Kyushu University, Research Center for Infectious Diseases, Fukuoka, Japan.

Published: 16 April 2015
} 


\section{References}

1. Kerscher B, Willment JA, Brown GD: The Dectin-2 family of C-type lectinlike receptors: an update. Int Immunol 2013, 25:271-277.

2. Miyake $Y$, Toyonaga $K$, Mori D, Kakuta $S$, Hoshino $Y$, Oyamada A, Yamada $H$, Ono K, Suyama M, Iwakura Y, et al: C-type lectin MCL is an FcRgammacoupled receptor that mediates the adjuvanticity of mycobacterial cord factor. Immunity 2013, 38:1050-1062.

3. Wilson GJ, Marakalala MJ, Hoving JC, van Laarhoven A, Drummond RA, Kerscher B, Keeton R, van de Vosse E, Ottenhoff TH, Plantinga TS, Alisjahbana B, Govender D, Besra GS, Netea MG, Reid DM, Willment JA, Jacobs M, Yamasaki S, van Crevel R, Brown GD: The C-Type Lectin Receptor CLECSF8/CLEC4D Is a key component of anti-mycobacterial immunity. Cell Host Microbe 2015, 17(2):252-259.

doi:10.1186/1476-9255-12-S1-P4

Cite this article as: Kerscher et al:: Characterisation of the murine C-type lectin receptor CLECSF8 (MCL) reveals its expression on cells of the Monocyte/Neutrophil lineages and an inter-dependence with Mincle, but not Dectin-2. Journal of Inflammation 2015 12(Suppl 1):P4.

\section{Submit your next manuscript to BioMed Central} and take full advantage of:

- Convenient online submission

- Thorough peer review

- No space constraints or color figure charges

- Immediate publication on acceptance

- Inclusion in PubMed, CAS, Scopus and Google Scholar

- Research which is freely available for redistribution

Submit your manuscript at www.biomedcentral.com/submit
Ciomed Central 